\title{
A PAM Control Method for Matrix Converter Based on Virtual AC/DC/AC Conversion Method
}

\author{
Akihiro Odaka Member (Fuji Electric Advanced Technolgy Co., Ltd.) \\ Ikuya Sato Member (Fuji Electric Advanced Technolgy Co., Ltd.) \\ Hideki Ohguchi Member (Fuji Electric Advanced Technolgy Co., Ltd.) \\ Yasuhiro Tamai Member (Fuji Electric Advanced Technolgy Co., Ltd.) \\ Hironori Mine Member (Fuji Electric Advanced Technolgy Co., Ltd.) \\ Jun-ichi Itoh Member (Nagaoka University of Technology)
}

Keywords: matrix converter, AC/DC/AC conversion, PAM control, total harmonic distortion, common-mode voltage

\section{Introduction}

Fig. 1(a) shows a matrix converter. The matrix converter (MC) has many features, as compactness, long life, low distortion input current, and so on. Because of those merits, PWM control strategies for the MC are actively carried on. In conventional PWM control strategies, the MC is PWM controlled by using maximum line-toline input voltage. On the other hand, novel PWM control methods are proposed recently. In those methods, the MC is controlled without using maximum line-to-line input voltage when the MC outputs low voltage. By using the method, accuracy of low output voltage can be improved. However, those methods are complicated because PWM control pattern in order to control input current and output voltage simultaneously has to be obtained directly (AC/AC direct method).

In this paper, a novel PWM control strategies based on a virtual indirect control method with a virtual rectifier and a virtual inverter (virtual AC/DC/AC method). By using this strategy, input current and output voltage can be controlled independently and the same effect as the strategies based on the AC/AC direct method can be obtained.

\section{Proposed Control strategy}

The proposed method is a PAM (Pulse Amplitude Modulation) control strategy based on a virtual AC/DC/AC method. Fig. 1(b) shows a virtual rectifier and a virtual inverter. In the proposed method, controlling a virtual DC link voltage with a rectifier controls output voltage amplitude. A virtual inverter controls only output frequency. A PWM control pattern for the MC is obtained by combing a rectifier control command and an inverter control command. Detail of the combing method is reported in full paper.

\section{Experimental results}

Fig. 2 shows experimental waveforms. A load of a prototype MC is induction motor $(188 \mathrm{~V} / 4$ pole $/ 750 \mathrm{~W})$. Line-to-Line input voltage is $200 \mathrm{~V} / 50 \mathrm{~Hz}$, carrier frequency is $10 \mathrm{kHz}$, and rotation speed of the motor is $500 \mathrm{r} / \mathrm{min}$. It can be seen that good sinusoidal input and output currents are obtained and maximum line-to-line input voltage is not outputted. From these results, validity of the proposed principle is confirmed.

Fig. 3 shows converter efficiency, THD of input current and THD of output current characteristics of the proposed method and conventional $\mathrm{AC} / \mathrm{DC} / \mathrm{AC}$ method. In the conventional method, two different inverter modulation strategies are used (2-phase, 3-phase modulation). From this figure, it is understood that efficiency of the proposed method is almost equal to that of the conventional method with 2-phase modulation. On the other hand, distortion of output current that has great influence on torque ripple is reduced compared

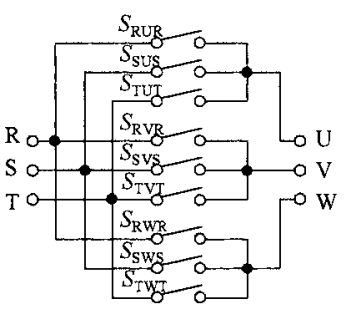

(a) Matrix converter

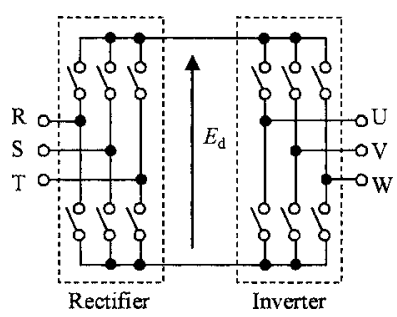

(b) $\mathrm{AC} / \mathrm{DC} / \mathrm{AC}$ converter
Fig. 1. Converter

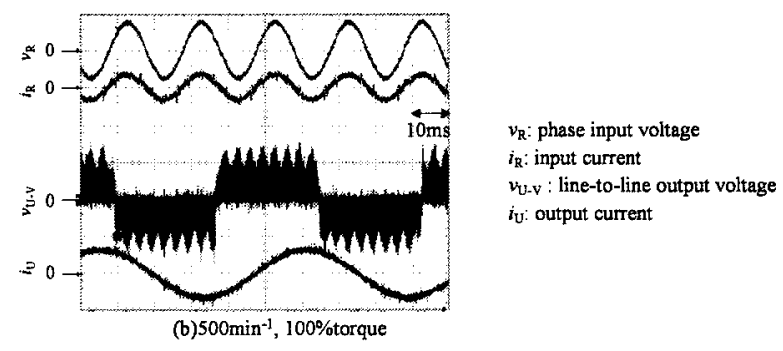

Fig. 2. Experimental waveforms

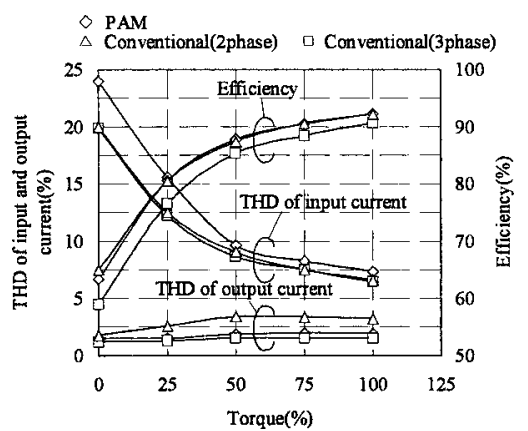

Fig. 3. THD of input and output current and converter efficiency characteristics

to that of the conventional method with 2-phase modulation.

\section{Conclusion}

In this paper, a novel PWM control strategies for the matrix converter based on a virtual AC/DC/AC method has been proposed. The validity of the proposed principle has been confirmed thorough experiment. Moreover, various characteristics of the proposed method and conventional virtual AC/DC/AC method are compared. As a result, THD of output current can be reduced without increasing converter loss. 


\title{
仮想 $\mathrm{AC} / \mathrm{DC} / \mathrm{AC}$ 変換方式に基づいた \\ マトリックスコンバータのPAM制御法
}

$\begin{array}{lll}\text { 正員 小高 } & \text { 章弘* } & \text { 正 員 佐藤以久也* } \\ \text { 正員 大口 } & \text { 英樹* 正 員 玉井 康寛* } \\ \text { 正員 美根 } & \text { 宏則* 正 員 伊東 淳一** }\end{array}$

\section{A PAM Control Method for Matrix Converter Based on Virtual AC/DC/AC Conversion Method}

\begin{abstract}
Akihiro Odaka*, Member, Ikuya Sato*, Member, Hideki Ohguchi*, Member, Yasuhiro Tamai*, Member, Hironori Mine*, Member, Jun-ichi Itoh**, Member
\end{abstract}

In this paper, a novel control method for a matrix converter is proposed. The proposed method is a PAM (Pulse Amplitude Modulation) control method based on a virtual AC/DC/AC conversion method. Output voltage amplitude is controlled by controlling a virtual DC link voltage with a virtual rectifier. Output frequency is controlled by a virtual inverter.

Firstly, the proposed method is explained. Next, the validity of the proposed method is confirmed thorough simulation and experiment using a $750 \mathrm{~W}$ prototype matrix converter. Moreover, various characteristics of the proposed method and conventional virtual AC/DC/AC method are compared through experiment. As a result of experiment, it has been understood that total harmonic distortion of output current and common-mode voltage can be reduced compared with the case of using a conventional virtual AC/DC/AC conversion method.

キーワード：マトリックスコンバータ, AC/DC/AC 変換, PAM 制御, 歪み率, コモンモード電圧

Keywords: matrix converter, $\mathrm{AC} / \mathrm{DC} / \mathrm{AC}$ conversion, PAM control, total harmonic distortion, common-mode voltage

1. はじめに

マトリックスコンバータは，従来のインバータシステム に比べて, 小型, 軽量, 高効率化等が期待されることから, 広く注目されている。ところで，マトリックスコンバータ の制御手法は，種々な方式が提案されており (1) (4) ,これまで の一般的な制御手法は入力の最大の大きさの線間電圧を用 いて PWM 変調を行う。それに対し, 近年では, マトリック スコンバータが低電圧を出力する際には，入力の最大の大 きさの線間電圧を利用せずに PWM 変調する方式 ${ }^{(5)(6)}$ が提 案されており，このような制御方式を用いることで，従来の 制御方式に比べて低電圧出力時に扔ける電圧精度が向上で きること等が報告されている(5)。しかしながら，この方式

\footnotetext{
*富士電機アドバンストテクノロジー（株）

干 191-8502 日野市富士町 1

Fuji Electric Advanced Technology Co., Ltd.

1, Fuji-machi, Hino 191-8502

** 長岡技術科学大学

干 940-2185 長岡市上富岡町 1603-1

Nagaoka University of Technology

1603-1, Kamitomioka-cho, Nagaoka 940-2185
}

は, 入力電圧から, 出力電圧指令と入力電流指令に見合った $\mathrm{PWM}$ パターンを直接生成するもので (以下, 直接 $\mathrm{AC} / \mathrm{AC}$ 方式と呼ぶ), PWM パルスの演算方法が従来の PWM イン バー夕とは大きく異なり複雑になると思われる。

そこで，本論文では，仮想 $\mathrm{AC} / \mathrm{DC} / \mathrm{AC}$ 方式に基づいて, 同様な効果が得られる新しい制御手法を提案する。仮想 $\mathrm{AC} / \mathrm{DC} / \mathrm{AC}$ 方式は, マトリックスコンバータを仮想の PWM 整流器とインバータに見立てて制御する手法であり, 従来 から扱い慣れたシステムに立脚しているため, 直接 $\mathrm{AC} / \mathrm{AC}$ 方式に比べて PWM パルスの演算が考えやすく, また，これ まで考案されている種々な PWM 整流器やインバー夕の制 御手法を容易に応用できると考える。本論文で提案する手 法は，仮想整流器で仮想直流電圧の大きさを制御すること により出力電圧の大きさを調整し, 仮想インバータでは出 力周波数の制御のみを行ういわゆる PAM (Pulse Amplitude Modulation）制御であり, 低電圧出力時には, 特別な制御を 施さずとも自動的に入力の最大線間電圧を用いずに PWM 制御することが可能になる。

本稿では，提案する PAM 制御の制御方法ついて明らか にするとともに，シミュレーションと実験により，提案し 
た原理の妥当性を確認する。また，提案手法と筆者らが既 に提案した仮想 $\mathrm{AC} / \mathrm{DC} / \mathrm{AC}$ 方式 (4)(7) との，入出力の電流歪 み率, 変換器効率, さらにはコモンモード電圧の特性の違 いを $750 \mathrm{~W}$ の誘導機を用いた実験により確認する。

\section{2. 仮想 $\mathrm{AC} / \mathrm{DC} / \mathrm{AC}$ 変換方式に基づいたマトリック スコンバータの PAM 制御の制御手法}

提案する PAM 制御手法は，図 1 に示すマトリックスコ ンバータを図 2 に示す仮想の整流器とインバータに分けて 考える点では，既に筆者らが提案した仮想 AC/DC/AC 変換 方式と同様である。しかしながら，従来は仮想整流器で仮 想直流電圧が理論最大電圧となるように制御し，仮想直流 電圧に基づき仮想インバータで出力電圧と周波数を制御す るのに対し，本手法では，仮想整流器で仮想直流電圧の大 きさを調節することで出力電圧の大きさを制御し，仮想イ ンバータでは出力周波数のみを制御する点で従来と異なる。 以下に，提案する PAM 制御手法について説明する。

$\langle 2 \cdot 1\rangle$ 仮想整流器の制御法仮想整流器は, 従来と 同様に電流形整流器として考える。また，本論文では入力 電流は力率が 1.0 の正弦波電流となるように制御するもの とし， $\theta$ を電源位相角として 3 相入力電流指令を (1) 式で 表す。

$$
i_{R}{ }^{*}=\cos (\theta), i_{S}{ }^{*}=\cos (\theta-2 \pi / 3), i_{T}{ }^{*}=\cos (\theta-4 \pi / 3)
$$

入力電流の波形制御は 3 相入力電流のうち 2 相を制御す れば良いから，3相電流の各々の絶対值が最小の大きさに なる相と中間の大きさになる相との 2 相の電流波形制御を

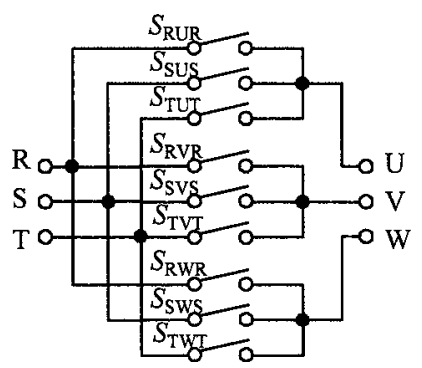

図 1 マトリックスコンバータ

Fig. 1. Matrix Converter.

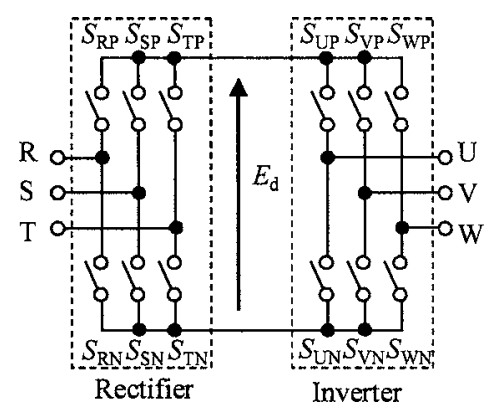

図 $2 \mathrm{AC} / \mathrm{DC} / \mathrm{AC}$ 変換回路

Fig. 2. AC/DC/AC Converter.
考える（厳密には最小の大きさの相と中間の大きさの 2 相 に限定するものではないが，ここでは容易に説明するため， このように仮定する）。また，電圧利用率を極力高くするた め，仮想直流回路には，入力の最大および中間の大きさの 線間電圧 (以下，それぞれ入力最大線間，中間線間電圧と 呼ぶ）を接続することを考える。これら，入力電流波形制 御，仮想直流電圧制御の考え方を基に，1キャリア毎に(2) 式で表せるデューティ比率で, 入力最大, 中間線間電圧を 仮想直流回路に接続することで，入力電流を正弦波化する ことと仮想直流電圧を任意の一定の大きさに調整すること が可能になる。ここで，(2) 式中， $k$ は仮想直流電圧の大き さの調整要素である。

$$
\begin{aligned}
& D_{\text {REC_mid }}=k \cdot \operatorname{mid}\left(\left|i_{R}{ }^{*}\right|,\left|i_{S}{ }^{*}\right|,\left|i_{T}{ }^{*}\right|\right) \\
& D_{\text {REC_min }}=k \cdot \min \left(\left|i_{R}{ }^{*}\right|,\left|i_{S}{ }^{*}\right|,\left|i_{T}{ }^{*}\right|\right)
\end{aligned}
$$

但し, $D_{\text {REC_mid }}$ : 最大線間電圧一仮想直流回路接続デュー ティ, $D_{\mathrm{RECmin}}$ : 最小線間電圧一仮想直流回路接続デューティ

尚, 電流形整流器なので, 入力最大, 中間線間電圧何れ も仮想直流回路に接続されない期間は，仮想整流器の上下 アームを短絡させ，仮想直流回路を $0 \mathrm{~V}$ とする必要がある。 したがって，上下アームを短絡するデューティを $D_{\text {REC_0 }}$ と すれば， $D_{\text {REC_0 }}, D_{\text {REC_mid }}$ および $D_{\text {REC_min }}$ の間には，次の 関係が成立する。

$$
D_{\text {REC_mid }}+D_{\text {REC_min }}+D_{\text {REC_0 }}=1
$$

ここで，仮想直流電圧を $E_{\mathrm{d}}$ ，入力線間電圧実効值を $V_{\mathrm{S}}$ とすれば $k, V_{\mathrm{S}}$ および $E_{\mathrm{d}}$ の間には (4) 式の関係が成り立 つ。尚, $k>1$ の場合は過変調となり, 直流電圧を一定に 制御できず，また，入力電流も正弦波状とならない。

$$
k=\frac{2 \cdot E_{d}}{\sqrt{3} \cdot \sqrt{2} \cdot V_{S}}
$$

図 3 に, 入力相電圧 $v_{\mathrm{R}}, v_{\mathrm{S}}, v_{\mathrm{T}}$, 入力電流指令 $i_{\mathrm{R}}{ }^{*}, i_{\mathrm{S}}{ }^{*}$, $i_{\mathrm{T}}{ }^{*}$ および入力最大, 中間線間電圧が仮想直流回路に接続さ れる仮想整流器デューティ指令 $D_{\text {REC_mid, }} D_{\text {REC_min }}$ の例を 示す。

図 4 は例として, 図 3 中の矢印 $(\Leftrightarrow)$ で示した期間にお ける仮想整流器の動作を示したものである。この期間にお いて，入力最大線間電圧，中間線間電圧は，それぞれ $v_{\mathrm{RT}}$,

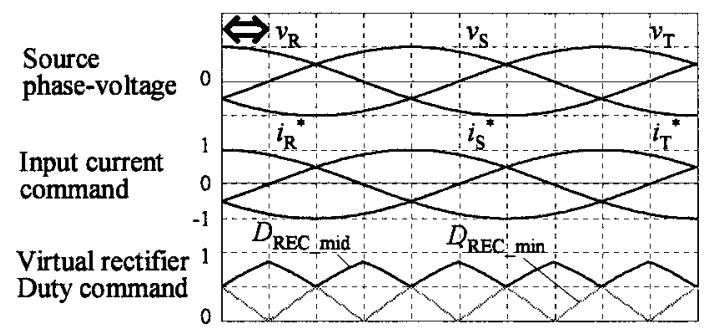

図 3 入力相電圧, 入力電流指令および仮想整流器 デューティ指令

Fig. 3. Input phase voltage, input current command and virtual rectifier duty command. 


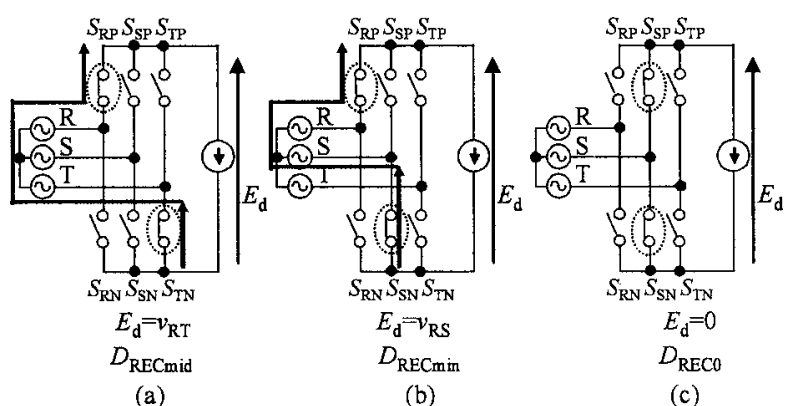

図 4 仮想整流器の動作

Fig. 4. Operation of virtual rectifier.

$v_{\mathrm{RS}}$ である（線間電圧の記号の添字は，例えば $v_{\mathrm{RT}}$ の場合， $\mathrm{T}$ 相に対して $\mathrm{R}$ 相の電位が高いことを意味する)。従って, 1 キャリア毎に, 先ず, 図 4(a) に示すように, デューティ 指令 $D_{\text {REC_mid }}$ に基づいたデューティ比率で仮想整流器のス イッチ $S_{\mathrm{RP}}$ と $S_{\mathrm{TN}}$ をオンすることで，入力最大線間電圧 $v_{\mathrm{RT}}$ を仮想直流回路に接続する。次いで，デューティ指令 $D_{\mathrm{REC} \_m i n}$ に基づいたデューティ比率でスイッチ $S_{\mathrm{RP}}$ と $S_{\mathrm{SN}}$ をオンし，入力中間線間電圧 $v_{\mathrm{RS}}$ を仮想直流回路に接続す る。1キャリア中において，入力最大，中間線間電圧も接 続されない残りの期間は, 図 4(c) に示すようにデューティ 比率 $D_{\text {REC_0 }}$ で, 仮想整流器の上下アームを短絡させる。こ こで，図 4(a), (b) に示すように, 入力電流は, 最小の大き さの相電圧（ここでは， $\mathrm{T}$ 相。以下，入力最小相 $v_{\min }$ ), 中 間の大きさの相電圧（ここでは， $\mathrm{S}$ 相。以下，入力中間相 $v_{\text {mid }}$ ）を介して電流が流れるが，これらは，(1)(2) 式で明ら かなように正弦波変調されているため, 入力電流の正弦波 化が可能となる。

さて，図 4 は，入力中間相 $v_{\text {mid }}$ の極性が負の場合の動 作を示したものであるが，この場合，最大の大きさの相電 圧（以下，入力最大相 $v_{\max }$ ）が仮想直流回路に接続される 期間は， $D_{\text {REC_mid }}+D_{\text {REC_min }}$ となり，入力最小相 $v_{\text {min }}$ が 仮想直流回路に接続される期間は $D_{\text {REC_mid }}$ となる。一方, 入力中間相の極性が正の場合（極性が負の場合と動作が対 象となるので，動作図は省略する）は，入力最大，最小相 が仮想直流回路に接続される期間は，それぞれ， $D_{\text {REC_mid }}$, $D_{\text {REC_mid }}+D_{\text {REC_min }}$ となる。これらのことはマトリックス コンバータの制御指令を考える上で重要な意味を持つが詳 細は後述する。

$\langle\mathbf{2} \cdot \mathbf{2}\rangle$ 仮想インバータの制御法仮想直流電圧が仮 想整流器によって制御されているので，仮想インバータの 変調信号は，変調率を固定し，所望の出力周波数となるよ うに周波数のみを変化させればよい。尚，本論文では，電 圧利用率を高めることを目的として，一般に良く知られて いる 2 相変調方式を用いる。

図 5 に, 仮想インバータの上アームのオンデューティ指令 $D_{\text {INV_U }}, D_{\text {INV_V }}, D_{\text {INV_W }}$ の波形を示す。図に示すデュー ティ指令とした場合，出力線間電圧の基本波実効值を $V_{\mathrm{L}}$ と すれば，仮想直流電圧 $E_{\mathrm{d}}$ との $V_{\mathrm{L}}$ の間には，(5) 式の関係が

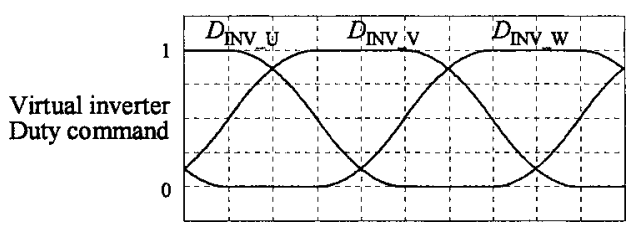

図 5 仮想インバータデューティ指令

Fig. 5. Virtual inverter duty command.

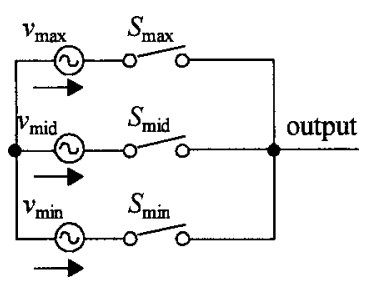

図 6 マトリックスコンバータ出力 1 相等価回路

Fig. 6. Matrix converter equivalent circuit of output one phase.

成り立つ。したがって, 出力電圧の大きさは，(4) 式と (5) 式の関係を用いて, 仮想整流器で仮想直流電圧の大きさを 調節することで制御する。

$$
E_{d}=\sqrt{2} \cdot V_{L}
$$

〈2·3〉 マトリックスコンバータの制御指令の計算法 さて，前節までは仮想整流器と仮想インバータの制御に ついて議論したが，本節では，仮想システムからマトリッ クスコンバータへの制御指令の変換について述べる。

マトリックスコンバータの各スイッチのオンデューティ 指令は, 図 6 に示すように, 出力 1 相に接続されている 3 つのスイッチを 1 単位として考え, 入力最大相 $v_{\max }$, 中間 相 $v_{\text {mid }}$, 最小相 $v_{\min }$ を, それぞれ出力に接続するスイッチ $S_{\text {max }}, S_{\text {mid }}, S_{\text {min }}$ のオンデューティを考える。ここで, 図 2 と図 6 から明らかなように，マトリックスコンバータのス イッチ $S_{\max }$ は, 仮想整流器が入力最大相を仮想直流回路の 正極側に接続しており，かつ，仮想インバータの上アームが オンしている際にオンする。したがって，スイッチ $S_{\max }$ は 仮想整流器が入力最大相を仮想直流回路に接続している期 間を基準に，仮想インバータの上アームデューティ指令に 基づいたデューテイ比率でオンすれば良い。一方，スイッ チ $S_{\min }$ も同様に, 仮想整流器が入力最小相を仮想直流回 路に接続している期間を基準に, 仮想インバータの下アー ムがオンするデューティ比率でオンすれば良い。ここで, $\langle 2 \cdot 1\rangle$ 節で述べた, 仮想整流器が, 入力最大, 最小相をそ れぞれ仮想直流回路に接続するデューティより，例えば出 力 U 相に接続されたスイッチ $S_{\operatorname{maxU}}, S_{\operatorname{minU}}$ それぞれのオ ンデューティ $D_{\operatorname{maxU}}, D_{\mathrm{minU}}$ は, 次式で表せる。

$$
\begin{cases}D_{\mathrm{maxU}}=D_{\text {REC_max }} \cdot D_{\mathrm{INV} \_\mathrm{U}} & (\text { 入力中間相電圧 }<0) \\ D_{\mathrm{maxU}}=D_{\text {REC_mid }} \cdot D_{\mathrm{INV} \_\mathrm{U}} & (\text { 入力中間相電圧 }>0)\end{cases}
$$


$\left\{\begin{array}{l}D_{\text {minU }}=D_{\text {REC_mid }} \cdot\left(1-D_{\text {INV_U }}\right)(\text { 入力中間相電圧 }<0) \\ D_{\text {minU }}=D_{\text {REC_max }} \cdot\left(1-D_{\text {INV_U }}\right)(\text { 入力中間相電圧 }>0)\end{array}\right.$

但し,

$D_{\text {REC_max }}=D_{\text {REC_mid }}+D_{\text {REC_min }}=k \cdot \max \left(\left|i_{R}{ }^{*}\right|,\left|i_{S}{ }^{*}\right|,\left|i_{T}{ }^{*}\right|\right)$

ここで，図 6 に示す 3 つのスイッチのオンデューティの 和は 1 であるから，入力中間相を出力 $\mathrm{U}$ 相に接続するス イッチ $S_{\text {midU }}$ のオンデューティ $D_{\text {midU }}$ は (9) 式で表せる。 これは，スイッチ $S_{\text {mid }}$ がオンする期間は，仮想整流器が仮 想直流回路を $0 \mathrm{~V}$ とする期間を含むことを意味する。すな わち，仮想整流器が仮想直流回路を $0 \mathrm{~V}$ とする期間を，マ トリックスコンバータでは, 出力相を入力中間相に接続す ることで実現することになる。

$$
D_{\text {midU }}=1-D_{\text {maxU }}-D_{\text {minU }}
$$

〈2・4〉PWM パルス生成法ここれまで，説明したデ ユーティ指令からマトリックスコンバータの PWM パルス を生成する手法については，既に筆者らが提案した手法 ${ }^{(7)}$ と同様である。図 7 に例として出力 $\mathrm{U}$ 相の PWM パルス 生成回路を示す。比較器 comparator1 では，デューティ指 令 $D_{\text {midU }}$ と $D_{\operatorname{minU}}$ の和とキャリア三角波とを比較し, また, 比較器 comparator2 では, デューティ指令 $D_{\operatorname{minU}}$ とキャリ ア三角波とを比較し，それら比較結果を図に示す論理演算 をすることにより，U 相スイッチ $S_{\operatorname{maxU}}, S_{\mathrm{midU}}, S_{\mathrm{minU}}$ の $\mathrm{PWM}$ パルスを得る。このような手法により，1 キャリア周 期内で， 3 つの入力相電圧が最大相 $v_{\text {max }} \rightarrow$ 中間相 $v_{\text {mid }} \rightarrow$ 最小相 $v_{\min } \rightarrow$ 中間相 $v_{\text {mid }} \rightarrow$ 最大相 $v_{\max }$ の順番で接続され ることになる。尚，この手法によって得られた U 相スイッ チの PWM パルスは, 電源位相に応じて, 図 1 に示すスイッ チ $S_{\mathrm{RUR}}, S_{\mathrm{SUS}}, S_{\mathrm{TUT}}$ に分配する。他相も同様である。

〈2·5〉 PAM 方式の制御ブロック 図 8 に,これま で説明したことをまとめた PAM 方式の制御ブロック図を, 図 9 に, 文献 (4) (7) で示されている従来の仮想 AC/DC/AC 方式 (以下, 従来方式と呼ぶ) の制御ブロック図を示し, 本 制御方式と従来方式との相違点について述べる。

図 8 に示す本制御方式において, ABS は絶対值の意であ り，また， max, midは，それぞれ，3つの入力の最大，中 間の大きさを抽出するものであり，(2), (8) 式で説明したこ とによる。これまで説明してきたように，本制御方式では， 出力電圧の振幅指令 $V_{\mathrm{O}}{ }^{*}$ に応じて, 仮想整流器デューティ 指令 $D_{\text {REC_max }}, D_{\text {REC_mid }}$ を調節することで，仮想直流電圧 $E_{\mathrm{d}}$ の大きさを調整し, 出力電圧の大きさを制御する。また, 出力周波数は, 3 相出力相電圧指令の基準信号となる位相指 令 $v_{\mathrm{U} 0}{ }^{*}, v_{\mathrm{V} 0}{ }^{*}, v_{\mathrm{W} 0}{ }^{*}$ の周波数, すなわち仮想インバータの出 力周波数指令を調整することにより制御する。マトリック スコンバータの PWM パルスは, 仮想整流器のデューティ 指令 $D_{\text {REC_max }}, D_{\text {REC_mid }}$ と仮想インバータのデューティ指

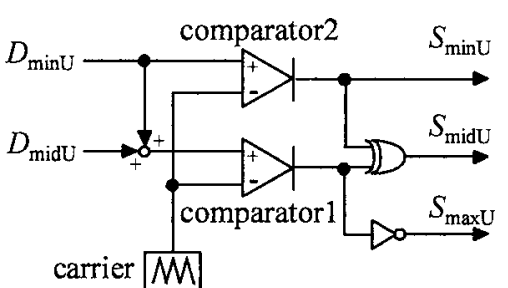

困 7 PWM パルス生成回路

Fig. 7. PWM pulse generating circuit.

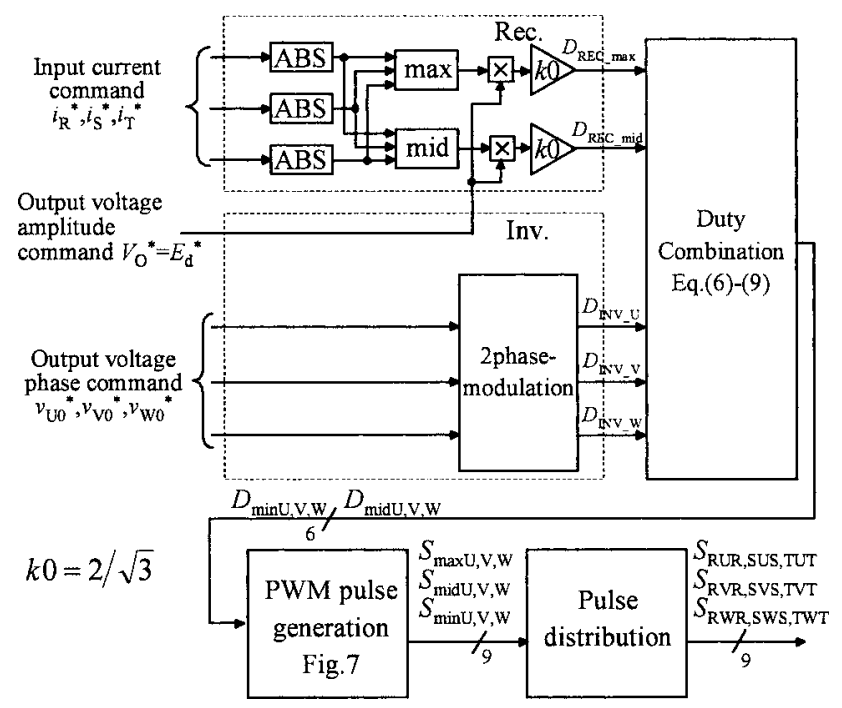

図 8 PAM 方式の制御ブロック

Fig. 8. Block diagram of PAM control method.

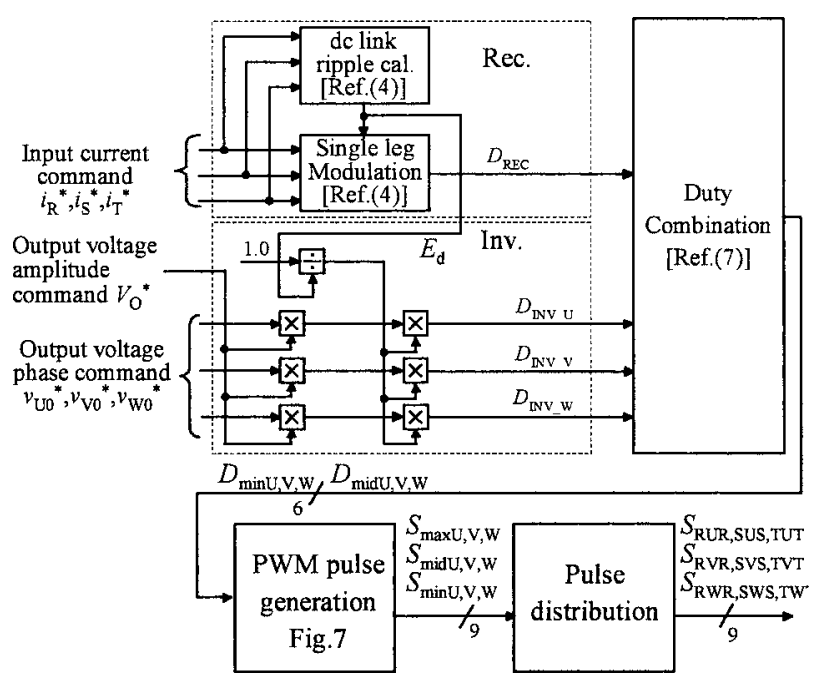

図 9 従来方式の制御ブロック

Fig. 9. Block diagram of conventional control method.

令 $D_{\text {INV_U }}, D_{\text {INV_V }}, D_{\text {INV_W }}$ とを (6) から (9) 式に基づい て Duty Combination 部で合成し, 図 7 に示した手法によ り, 入力最大, 中間, 最小相と出力相とを接続するスイッ チの $\mathrm{PWM}$ パルス $S_{\operatorname{maxU}} \sim S_{\operatorname{minW}}$ を得る。得られた $\mathrm{PWM}$ パルスは, 電源位相に応じてマトリックスコンバータを構 成する各スイッチの $\mathrm{PWM}$ パルス $S_{\mathrm{RUR}} \sim S_{\mathrm{TWT}}$ として分配 する。 
図 9 に示す従来方式では，スイッチング損失の低減と電 源電圧の利用率を高くすることを目的として, 仮想整流器 の制御に 1 レッグ変調（Single leg modulation）を用い, 仮 想整流器のデューティ指令 $D_{\mathrm{REC}}$ を得る。1 レッグ変調を 用いた場合，仮想直流電圧 $E_{\mathrm{d}}$ には，電源周波数の 6 倍の周 波数の電圧変動が生じる。尚, 出力電圧の大きさに関わら ず仮想直流電圧の平均的な大きさは一定となる。一方，仮 想インバータのデューティ指令 $D_{\mathrm{INV} \_\mathrm{U}}, D_{\mathrm{INV} \_\mathrm{V}}, D_{\mathrm{INV}} \mathrm{W}$ は, 3 相出力相電圧指令の基準信号 $v_{\mathrm{U}}{ }^{*}, v_{\mathrm{V} 0}{ }^{*}, \quad v_{\mathrm{W} 0}{ }^{*}$ と出 力電圧振幅指令 $V_{\mathrm{O}}{ }^{*}$ とを乗算することにより得たインバー 夕指令を, dc link ripple cal 部で計算した仮想直流電圧 $E_{\mathrm{d}}$ で除算することにより得られる。すなわち，仮想インバー 夕では, 仮想直流電圧の変動を補償しつつ, 出力電圧の大 きさと周波数を調整する。得られた仮想整流器と仮想イン バータのデューティ指令は, Duty Combination 部で合成さ れ，図７に示した手法により，マトリックスコンバータを 構成する各スイッチの $\mathrm{PWM}$ パルス $S_{\mathrm{RUR}} \sim S_{\mathrm{TWT}}$ が得られ る。尚, 図 9 において, 仮想インバータの 2 相変調を行う ブロックを記載していないが, 従来方式に打いても PAM 方 式と同様に 2 相変調を実施することも可能である。

このように, 従来方式では, 仮想整流器で仮想直流電圧 の大きさを制御せず，また，仮想インバータで，仮想直流 電圧に基づき出力電圧と周波数を制御するのに対し, 本制 御方式では, 仮想整流器で仮想直流電圧の大きさを調節す ることで出力電圧の大きさを制御し, 仮想インバータでは 出力周波数のみを制御する点で従来と異なる。

\section{3. シミュレーション結果}

図 10 は，提案するPAM 方式を用いた場合，図 11 は, 従 来方式を用いた場合の出力電圧のシミュレーション結果で ある。両図に打いて (a)(b) は，それぞれ低電圧㧍よび高電 圧 (ここでは, それぞれ，電源電圧実効值の 0.375 倍, 0.866 倍の出力線間電圧基本波実効值) を出力している際の 1 キャ リア周期分の波形であり, 上から, 電源中性点から観測し た出力相電圧 $v_{\mathrm{U}}, v_{\mathrm{V}}, v_{\mathrm{W}}$, 出力線間電圧 $v_{\mathrm{UV}}, v_{\mathrm{VW}}, v_{\mathrm{WU}}$, $\mathrm{PWM}$ パルス $S_{\operatorname{maxU}} \sim S_{\operatorname{minW}}$ を示している。尚, シミュレー ションにおいて，制御の基本原理を確認するため，転流は 理想転流（転流時間ゼロ）とし，また，従来方式では，仮 想インバータの制御方式を 2 相変調とした。

図11(a)より, 従来方式では, 低電圧出力時に, 入力最大 線間電圧 $v_{\max }-v_{\min }$ を出力線間電圧として出力しているの に対し，図 10(a)より，PAM 方式では，入力最大線間電圧 $v_{\max }-v_{\min }$ を出力していないことがわかる。一方, 図 10(b), 図 11(b)より, 高電圧出力時には, 両方式ともに, 入力最 大線間電压 $v_{\max }-v_{\min }$ を出力線間電圧として出力している ことがわかる。このように, PAM 方式に扔いて, 低電圧出 力時に入力の最大線間電圧を用いずに PWM 制御できるの は，低電圧出力時には仮想直流電圧を小さくするため， 1 キャリア周期内で仮想直流回路を $0 \mathrm{~V}$ とする期間が長くな り, (9) 式で説明したことから, スイッチ $S_{\text {mid }}$ のオンデュー

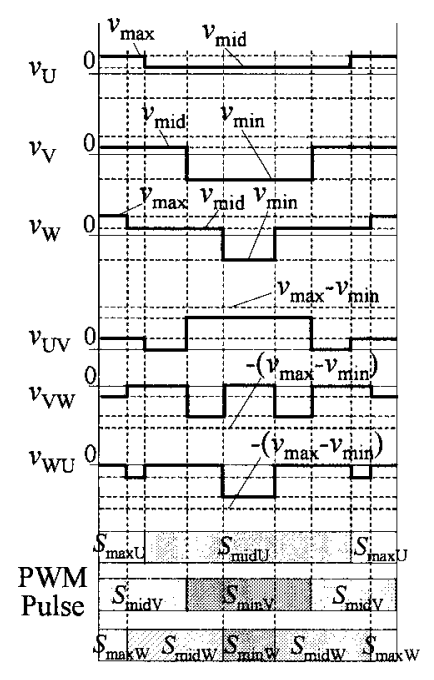

(a) Low output voltage.

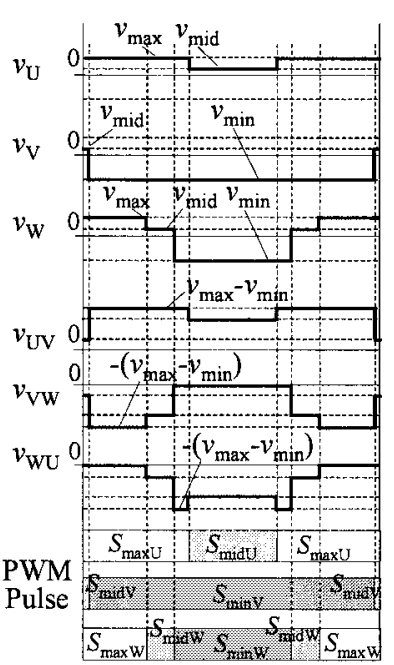

(b) High output voltage
図 10 PAM 方式のシミュレーション結果

Fig. 10. Simulation results of PAM control method.

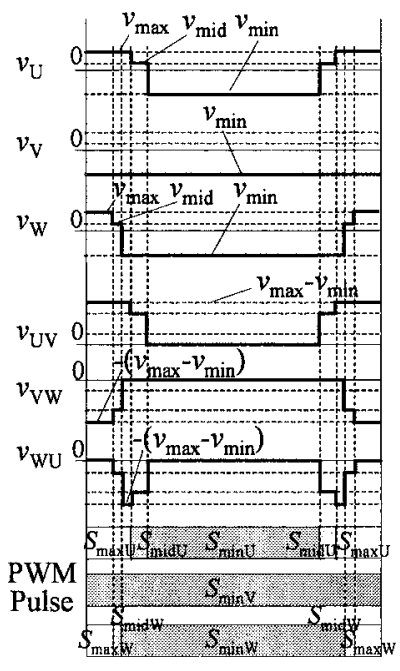

(a) Low output voltage.

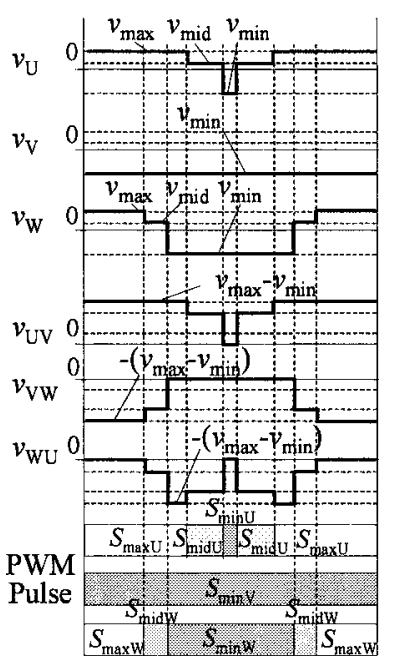

(b) High output voltage.
図 11 従来方式のシミュレーション結果

Fig. 11. Simulation results of conventional control method.

ティ $D_{\mathrm{mid}}$ が増加し, 入力最大線間電圧を出力しない $\mathrm{PWM}$ パルスが生成されるからである。

図 12 に, 提案する PAM 方式の入力電流と出力電圧のシ ミュレーション波形を示す。入力電圧は $200 \mathrm{~V} / 50 \mathrm{~Hz}$, 負荷 は静止負荷 $1.119 \Omega$ (力率 0.85 ), キャリア周波数は $10 \mathrm{kHz}$ とし, 出力線間電圧の基本波実効値として, $173.3 \mathrm{~V} / 40 \mathrm{~Hz}$ と $75 \mathrm{~V} / 40 \mathrm{~Hz}$ の 2 つ条件について行った。尚, 転流は理 想転流とした。波形は, 上から電源 $\mathrm{R}$ 相電圧 $v_{\mathrm{R}}, \mathrm{R}$ 相入 力電流に観測用ローパスフィルタを介した波形 $i_{\mathrm{R}(\mathrm{LPF})}$, 出 力 $\mathrm{UV}$ 間線間電圧 $v_{\mathrm{UV}}$ および出力 $\mathrm{UV}$ 間線間電圧に観測用 ローパスフィルタを介した波形 $v_{\mathrm{UV}(\mathrm{LPF})}$ を示す。また, 出力 $\mathrm{UV}$ 間線間電圧 $v_{\mathrm{UV}}$ と併せて, 入力最大線間電圧 $v_{\max }-v_{\min }$ を破線で示す。 


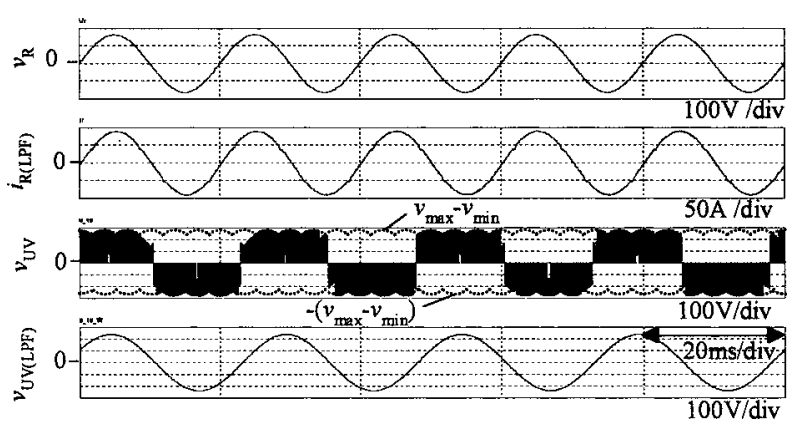

(a) Output line-line voltage (fundamental) $=173.3 \mathrm{~V}$

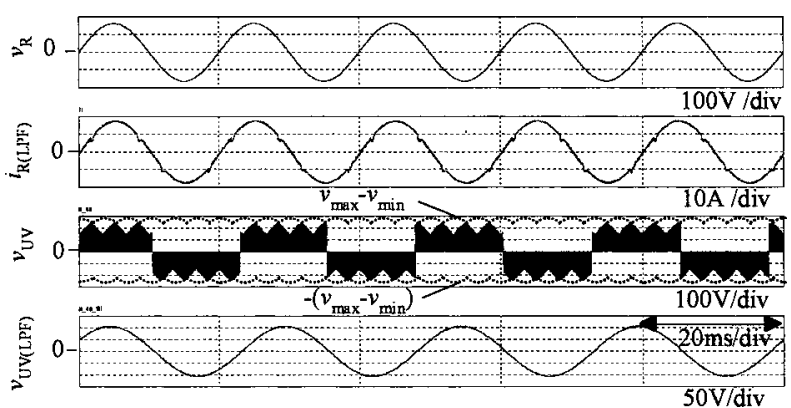

(b) Output line-line voltage (fundamental) $=75 \mathrm{~V}$

図 12 シミュレーション結果

Fig. 12. Simulation results.

図 12 より，良好な入力電流，出力電圧波形が得られてお り，理論の妥当であることが確認できる。また，図 12(a)よ $\eta$, 高電圧出力時には, 入力最大線間電圧 $v_{\max }-v_{\min }$ を用 いて PWM 制御され，マトリックスコンバータの理論最大 電圧 (電源電圧実効値の 0.866 倍の出力電圧基本波実効值) を出力できている。一方, 図 12(b) より, 低電圧出力時に は, 入力の最大線間電圧 $v_{\max }-v_{\min }$ を用いずに $\mathrm{PWM}$ 制御 できている。このように，提案する PAM 方式では，低電圧 出力時に，制御手法を切り替える等の特別な処理を施さず とも自動的に入力の最大線間電圧を用いずに PWM 制御さ れ，また，マトリックスコンバータの理論最大電圧である 電源電圧の 0.866 倍の電圧を出力することが可能である。

\section{4. 実験結果}

PAM 方式により，誘導機（188 V/750 W/4 極）を負荷と して実験を行った。入力電圧は $200 \mathrm{~V} / 50 \mathrm{~Hz}$ ，キャリア周 波数は $10 \mathrm{kHz}$ とし，電動機制御はベクトル制御を用いた。 また，シミュレーション条件に対し，転流動作を付加して おり，仮想インバータで転流誤差補償 ${ }^{(8)}$ を行っている。

図 13(a)(b)に，電動機回転数を $1000 \mathrm{~min}^{-1} ， 500 \mathrm{~min}^{-1}$ とし，負荷トルクを $100 \%$ とした場合の実験波形を示す。波 形は，上から電源 $\mathrm{R}$ 相電圧 $v_{\mathrm{R}}, \mathrm{R}$ 相入力電流（LCフィル 夕を介した波形） $i_{\mathrm{R}}$, 出力 $\mathrm{UV}$ 間線間電圧 $v_{\mathrm{UV}}$ 抢よび出力 電流 $i_{\mathrm{U}}$ である。図 13 より, シミュレーションと同様に良 好な入出力波形が得られており，また，図 13(b) 上り，回 転数が低い場合（出力電圧が低い場合）に揖いては，入力 の最大線間電圧を用いずに PWM 制御されていることが確

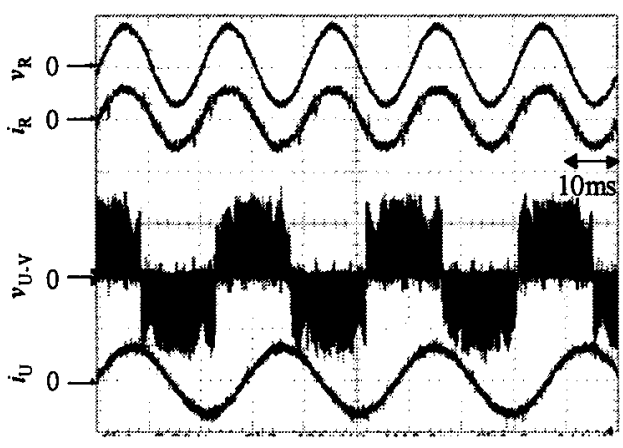

(a) $1000 \mathrm{~min}^{-1}, 100 \%$ torque

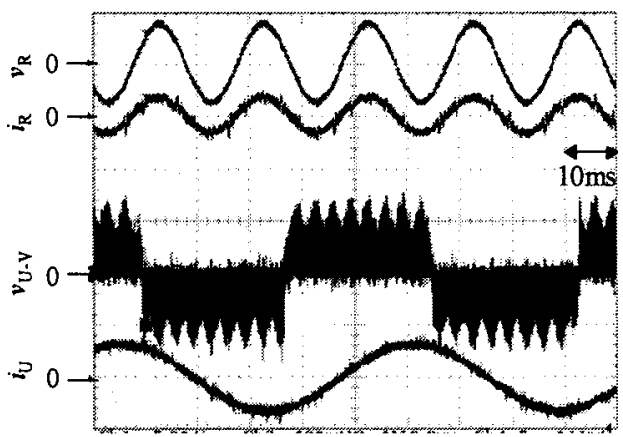

(b) $500 \mathrm{~min}^{-1}, 100 \%$ torque

$v_{\mathrm{R}}: 100 \mathrm{~V} / \mathrm{div}, i_{\mathrm{R}}: 5 \mathrm{~A} / \mathrm{div}, v_{\mathrm{U}-\mathrm{V}}: 200 \mathrm{~V} / \mathrm{div}, i_{\mathrm{U}}: 10 \mathrm{~A} / \mathrm{div}$

図 13 実験波形

Fig. 13. Experimental waveforms.

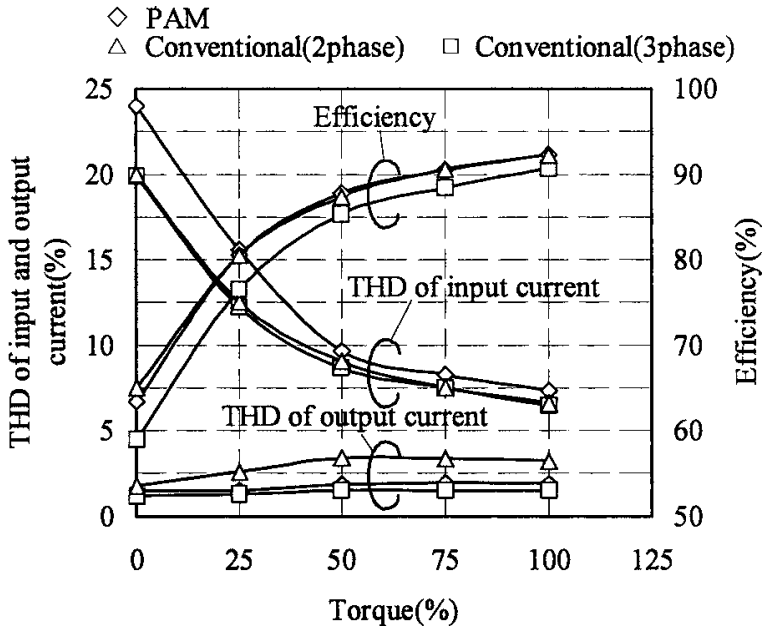

図 14 入力, 出力電流歪み率 THD, 変換器効率負荷トルク特性

Fig. 14. THD of input and output current and converter efficiency characteristics.

認できる。

図 14 は，電動機回転数を $1000 \mathrm{~min}^{-1}$ 一定とした場合に おいて, 負荷トルクに対する变換器効率, 入力電流と出力電 流の歪み率を, 提案する PAM 方式と従来の仮想 $\mathrm{AC} / \mathrm{DC} / \mathrm{AC}$ 方式(4)(7)(8) について比較を行った結果である。尚，従来方 式は, 仮想インバータの変調方式として 3 相変調と 2 相変 調それぞれを用いた場合について測定を行った。また，電 流の歪み率は基本波周波数の 20 次までの高次高調波を計 


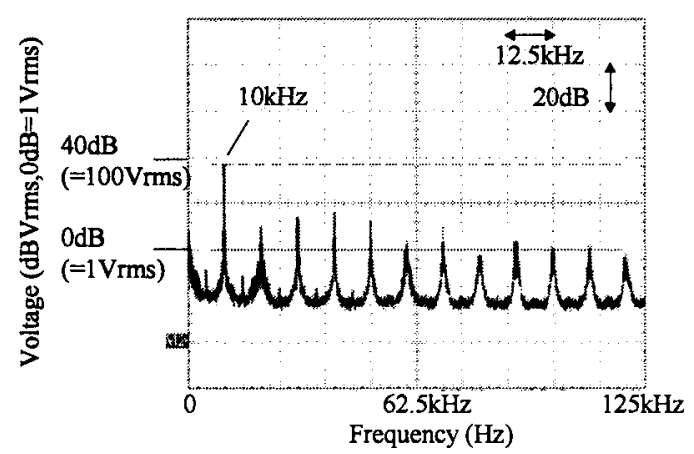

(a) PAM

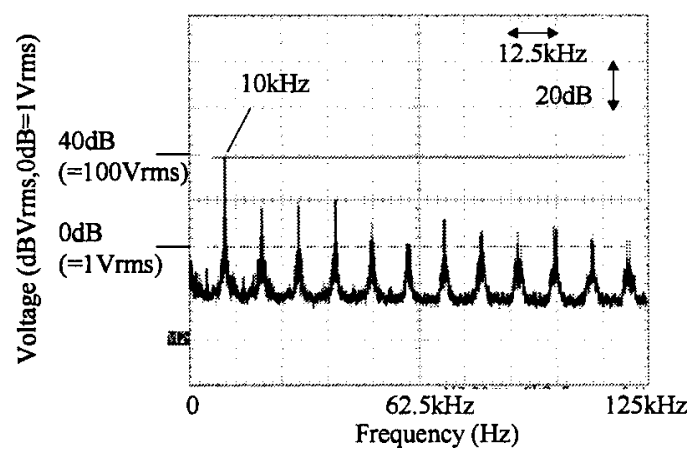

(b) Conventional (virtual inverter modulation : 3phase)

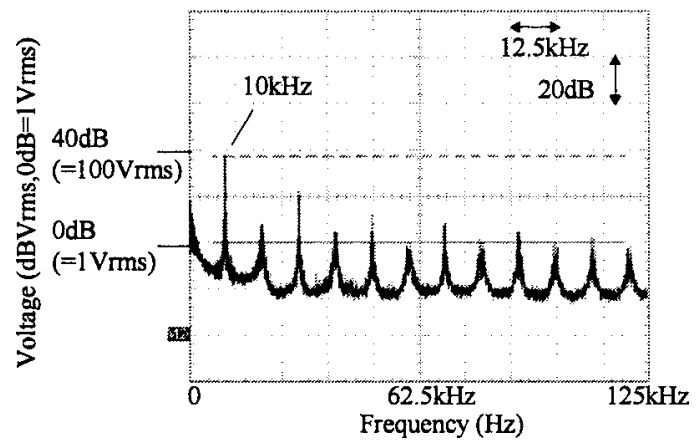

(c) Conventional (virtual inverter modulation : 2phase)

図 15 コモンモード電圧高調波

Fig. 15. Common-mode voltage harmonics.

算の対象とした。図より，PAM 方式は，低トルク時にお いて, 入力電流歪みが従来方式に比べて大きくなるものの 100\%卜ルク時には, 従来方式とほぼ同等になることが分か る。また，電動機制御に扔いて特に重要視される出力電流 の歪み率については，100\%卜ルク時において，従来方式で 仮想インバータを 2 相変調とした場合と同等の損失 (効率) で, 従来の 3 相変調とほほ同等の歪み率に改善できた。

図 15(a)(b)(c) は，マトリックスコンバータの制御手法と して PAM 方式と従来の仮想 $\mathrm{AC} / \mathrm{DC} / \mathrm{AC}$ 方式を用いた場合 のコモンモード電圧の高調波を測定した結果である。尚， 従来方式は，仮想インバータの変調方式として 3 相変調と 2 相変調を用いた場合について測定を行った。電動機の回 転数は, $1000 \mathrm{~min}^{-1}$ とした。

図 15(a)(b)より，PAM 方式は，従来方式で仮想インバー 夕を 3 相変調する場合と比較して, 全てのキャリア整数 倍成分のコモンモード電圧を低減できていること，また，
図 15(a)(c) より, 従来方式で仮想インバー夕を 2 相変調し た場合に対しては，特に，20 kHz 以下の低周波域で，キャ リア非整数倍成分を低減できていることが分かる。これら は，マトリックスコンバータの場合，コモンモード電圧が， 電源中性点から見た 3 つの出力相電圧の和により決定され るが，PAM 方式では，従来方式に比べて，1 キャリア周期 内で各出力相を入力中間相に接続する期間が長くなるため, コモンモード電圧の変動幅が従来に比べて小さくなるから である。

\section{5. まとめ}

本論文では，直接 $\mathrm{AC} / \mathrm{AC}$ 方式を用いて，マトリックス コンバータの低出力電圧時の電圧精度が向上できるとされ る変調方式を，仮想 $\mathrm{AC} / \mathrm{DC} / \mathrm{AC}$ 方式でも実現できる新しい 変調方式を提案した。

従来の仮想 $\mathrm{AC} / \mathrm{DC} / \mathrm{AC}$ 方式は, 仮想整流器で仮想直流 電圧が理論最大電圧となるように制御し，仮想直流電圧に 基づき仮想インバータで出力電圧と周波数を制御するのに 対し, 提案する手法は, 仮想整流器で仮想直流電圧の大き さを調節することで出力電圧の大きさを制御し，仮想イン バー夕では出力周波数のみを制御する，いわゆる $\mathrm{PAM}$ 方 式となる。

シミュレーションと $750 \mathrm{~W}$ 誘導機を用いた実験により， 良好な入力電流波形, 出力電圧波形が得られ, 提案原理の 妥当であることを確認した。また，従来の仮想 $\mathrm{AC} / \mathrm{DC} / \mathrm{AC}$ 変換方式と比較して, 従来方式と同等の発生損失で出力電 流歪みを低減できること，コモンモード電圧の低減が可能 であることを確認した。

今後は, 種々の変調方式を用いた場合における雑音端子 電圧やモータサージ電圧の違いについて検討を行う。

最後に本研究にご協力いただいた，長岡技術科学大学安 本竜志氏に感謝の意を表します。

(平成 17 年 9 月 22 日受付, 平成 18 年 1 月 24 日再受付)

$$
\text { 文献 }
$$

(1) M. Venturini: "A new sine wave in sine wave out conversion technique which eliminates reactive elements", in Proc. Powercon 7, pp.E3-1-E3-15 (1980)

(2) J. Oyama, T. Higuchi, E. Yamada, T. Koga, and T. Lipo: "New Control Strategy for matrix converter", Proc. Power Electronics Society Conf., pp.360367 (1989)

(3) A. Ishigro, T. Furuhashi, and S. Okuma: "A Novel Control Method for Forced Commutated Cycloconverters Using Input line to line voltage", Proc. International Power Electronics Conf., pp.761-766 (1990)

(4) J. Itoh, I. Sato, H. Ohguchi, K. Sato, A. Odaka, and N. Eguchi: "A Control Method for the Matrix Converter Based on Virtual AC/DC/AC Conversion Using Carrier Comparison Method", T. IEE Japan, Vol.124-D, No.5, pp.457-463 (2004-5) (in Japanese)

伊東淳一 ·佐藤以久也 - 大口英樹 - 佐藤和久 - 小高章弘 - 江口直也 : 「キャリア比較方式を用いた仮想 AC/DC/AC 変換方式によるマトリッ クスコンバー夕の制御法」, 電学論 D, 124, 5, pp.457-463 (2004-5)

(5) H. Hara, E. Yamamoto, M. Zenke, J. Kang, and T. Kume: "An Improvement of Output Voltage Control Performance for Low Voltage Region of Matrix Converter", Proc. of the 2004 Japan Industry Applications Society Conference, pp.I-313-I-316 (2004) (in Japanese) 
原 英則・山本栄治・善家充彦・姜 俊求・久米常生：「低電圧領域 に扔けるマトリクスコンバータの電圧改善の一方策」, 平 16 電気学 会産業応用部門全大, pp.I-313-I-316 (2004)

(6) H. Shimada and T. Takeshita: "PWM Control of Three-Phase to ThreePhase Matrix Converter for Reducing Output Voltage Harmonics", SPC-0548/IEA-05-3 (2005) (in Japanese)

島田大志・竹下隆晴 : 「出力電圧高調波の低減に着目した三相/三相 マトリックスコンバータの PWM 制御」, 半導体電力変換, 産業電力 電気応用合同研資, SPC-05-48/IEA-05-3 (2005)

(7) J. Itoh, H. Kodachi, A. Odaka, I. Sato, H. Ohguchi, and H. Umida: "A High Performance Control Method for the Matrix Converter Based on PWM generation of Virtual AC/DC/AC Conversion", Proc. of the 2004 Japan Industry Appl. Society Conf., pp.I-303-I-308 (2004) (in Japanese)

伊東淳一 - 小太刀博和 - 小高章弘 ·佐藤以久也 · 大口英樹 - 海田英 俊：「パルスパターンに着目した仮想 AC/DC/AC 変換方式によるマ トリックスコンバータの高性能化」, 平 16 電気学会産業応用部門全 大, pp.I-303-I-308 (2004)

(8) H. Ohguchi, J. Itoh, K. Kodachi, I. Sato, A. Odaka, and N. Eguchi: "An Improvement Scheme of Voltage Control Performance for Matrix Converter", SPC-03-135/IEA-03-47 (in Japanese)

大口英樹 · 伊東淳一 · 小大刀博和 $\cdot$ 佐藤以久也 · 小高章弘 ・江口直 也：「マトリックスコンバータの電圧制御性向上に関する研究」, 半 導体電力変換, 産業電力電気応用合同研資, SPC-03-135, IEA-03-47

小 高 章 弘（正員） 1973 年生。1998 年 3 月東京電機大学工

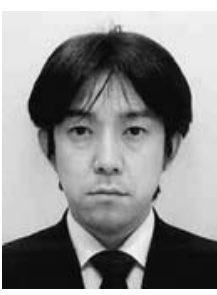
学研究科電気工学専攻修士課程修了。同年 4 月富 士電機（株）入社。現在，富士電機アドバンスト テクノロジー (株)。主として，電力変換回路の 研究に従事。

佐 藤 以久也（正員） 1976 年生。 2001 年 3 月明治大学大学院

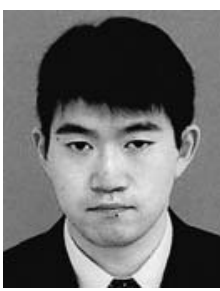
理工学研究科博士前期過程修了。同年 4 月富士電 機（株）入社。現在，富士電機アドバンストテク ノロジー (株)。主として電力変換回路，電動機 制御の研究に従事。

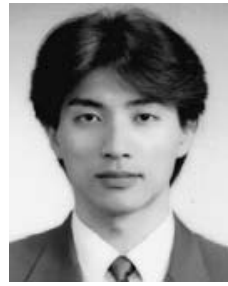

（正員）1974 年生。1999 年東京都立大 学工学研究科電気工学専攻修士課程卒業。2002 年 東京都立大学工学研究科博士課程修了。博士（工 学)。同年 4 月富士電機（株）入社。現在，富士 電機アドバンストテクノロジー (株)。主として, 電力変換回路の研究に従事。

玉 井 康 寛 (正員) 1980 年生。2004 年 3 月東京工業大学理

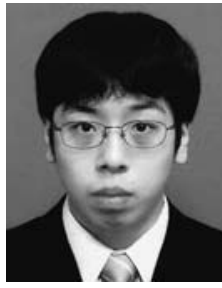
工学研究科修士課程修了。同年 4 月富士電機アド バンストテクノロジー（株）入社。主として，電 力変換回路の研究に従事。

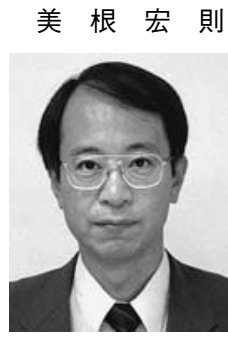

（正員） 1956 年生。1979 年 3 月東京大学工学部 電子工学科卒業。同年 4 月富士電機製造（株）入 社。現在，富士電機アドバンストテクノロジー (株)。主として, 電力変換回路の研究に従事。

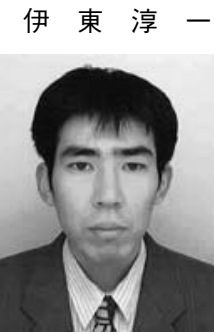

（正員）（正員）1972 年生。1996 年 3 月長岡技 術科学大学大学院工学研究科修士課程修了。同年 4 月富士電機（株）入社。2004 年 4 月長岡技術 科学大学助教授。主として電力変換回路, 電動機 制御の研究に従事。博士（工学）（長岡技術科学 大学)。 